\title{
Trophic transfer, bioaccumulation and Health risk assessment of heavy metal in Aras river, Case study: Amphipoda- Zander - Human
}

\section{Amir Dehghani ( $\sim$ a.dehghani93@gmail.com )}

Shahid Madani University of Azerbaijan: Azarbaijan Shahid Madani University https://orcid.org/00000002-6844-7293

\section{Atabak Roohi Aminjan}

Bu-Ali Sina University: Bu Ali Sina University

Allaverdi Dehghani

Tabriz University: University of Tabriz

\section{Research Article}

Keywords: Heavy metals, Food chain, Biomagnification, Aras River, Human health, THQ

Posted Date: April 5th, 2021

DOl: https://doi.org/10.21203/rs.3.rs-284077/v1

License: (9) This work is licensed under a Creative Commons Attribution 4.0 International License. Read Full License

Version of Record: A version of this preprint was published at Environmental Science and Pollution Research on January 7th, 2022. See the published version at https://doi.org/10.1007/s11356-021-180367. 


\section{Abstract}

This research investigates and traces heavy metals $(\mathrm{As}, \mathrm{Pb}, \mathrm{Cd}$ and $\mathrm{Cu})$ in a model of the aqueous food chain in the Aras River, located in northwestern of Iran. The selected model includes the zander (Sander lucioperca L.) and crustacean species known as amphipods (Gammarus spp.) that belong to the food chain of this fish. A total of 172 samples (70 fish and 102 Amphipoda) were collected randomly from the stations and analyzed for heavy metals using an Atomic Absorption Spectrophotometry (AAS). The results showed that the accumulation of heavy metals in both Taxon are in the order of $\mathrm{As}>\mathrm{Pb}>\mathrm{Cd}>\mathrm{Cu}$ and concentrations of heavy metals in fish body are higher than Gammarus spp. in every stations in different seasons. Specimens of station (1) due to industrial activities indicates the highest heavy metal content. The concentrations of $\mathrm{As}, \mathrm{Pb}$, and $\mathrm{Cd}$ exceedes the permissible limits. There is a close correlation between the concentration of heavy metals in the amphipod and zander. The target hazard quotient (THQ), Total target hazard quotient (TTHQ) and Carcinogenic Risk (CR) were calculated to assess human health risk. The average of THQ for As (1.43) exceedes the international standards and will endangere the consumers of this fish species. The TTHQ for heavy metals has been estimated highr than 1 . and at all stations, the value of $\mathrm{CR}_{\mathrm{Cd}}>1 \times 10^{-3}$, which reveals the degree of evidence of carcinogenicity of this metal in all parts of the Aras River. Therefore, according to results, effective controls and regular monitoring should be established in this regions

\section{Introduction}

Heavy metals are frequently released into the freshwater ecosystems from natural sources such as volcanic eruptions, forest fires, aerosols formation, and artificial sources which include industrial activities, agricultural activities, petroleum refinery waste, and mining (Mohammed et al. 2011). Some of the metals such as chromium, nickel, copper, and iron play a significant role in biological systems, while some heavy metals such as mercury, arsenic, lead, and cadmium are non-essential metals and extremely toxic (Ouyang et al. 2002; Hogan 2010). These metals exist at low concentrations in air, water, and soil, but human activities can increase their harmful concentration on ecosystems (Zhang et al. 2012). These metals bring in various long-term diseases for human being; for instance, excessive exposure to Cd may give rise to cancer, pulmonary diseases, and Alveolitis, while high $\mathrm{Zn}$ content has critical effect on reproduction (Tchounwou et al. 2012).

According to previous studies, fishes and aquatic invertebrates such as amphipods are suitable bioindicators for monitoring environmental contaminants such as heavy metals (Uysal et al. 2009; Kalyoncu et al. 2012). These organisms often are frequently exposed to metals contamination and they are valid indicative factors in freshwater ecosystems (Asuquo et al., 2004). Studies on bioaccumulation of pollutants in these organisms can be used to assess the trace metal pollution, biomagnification through food chains and the quality of aquatic ecosystems (Kiffney et al. 1994; Rashed 2001; Jelassi et al. 2015, Subotić et al. 2013). 
Dissolved metals in the environmental water are absorbed through the fish gills, cuticle of amphipods, and other sensitive organs of aquatic organisms (Guerra-García et al. 2010). Heavy metals may enter the human body indirectly through the food chain (Malvandi and Alahabadi 2019). For example, zander feed on amphipods can indirectly transfer heavy metals to human communities (Fig 1).

Amphipoda is an order of crustaceans with 9000 described species and found in marine, freshwater (such as Gammarus), and terrestrial habitats. They are in the food chains of many freshwater organisms such as fishes (Glazier et al. 2014). This order has a wide trophic range, feeding as herbivores, detritophages, and variety of prey (Kunz et al. 2010). One of the predator of Gammarus in freshwater is Zander. The Zander is a species from the Percidae family which most frequently found in the Aras River (Coad 2016). This fish is an important resource as food for human consumers of this region (Nasehi et al. 2013).

Many researches have been conducted regarding the accumulation of heavy metals in Pikeperch and Amphipoda (Ahsanullah and Williams 1991; Altındağ and Yiğit 2005; Yildirim et al. 2009; Fialkowski et al. 2009; Mazej et al. 2010; Gül et al. 2011; Özparlak et al. 2012; Subotić et al. 2013; Noël et al. 2013; Strode and Balode 2013; Bach et al. 2014; Alipour and Banagar, 2018; Bessa et al. 2017; Khemis et al. 2017; Jelassi et al. 2019; Kontchou et al. 2020) while only a limited studies are related to the Aras river (Nasehi et al. 2013; Farsani et al. 2019). Based on the mentioned literature, the accumulation of these elements in tissue of organisms diverse is a function of the different zones but depends on species, feeding behavior, ecological and physiological conditions, age, sexual characteristics, and migration.

The important goals of this study are (1) assessing the concentration of heavy metals $(\mathrm{As}, \mathrm{Pb}, \mathrm{Cd}, \mathrm{Cu})$ in the edible tissues of zander and its prey (Gammarus), (2) comparing seasonal changes of concentrations of these elements, (3) assessment of cancer and non-cancer risks for human associated with consumption of zander, and (4) introducing an index group to assess the harmful metals.

\section{Methods And Materials}

\section{study area and sampling sites}

The study was carried out along the Aras River (Fig 2). The Aras River with the length of $1072 \mathrm{~km}$, origins from Turkey and stretches for $460 \mathrm{~km}$ at the common borderline of Iran, Armenia, and Azerbaijan countries. This river discharges into Caspian Sea and has one of the most important aquatic ecosystems in the world with a complex ecological diversity and natural resources (Çelekli et al. 2020). Also, this river is considered as an important drinking water resource for several countries in the world such as Iran, Armenia, Azerbaijan, and Turkey. Therefore, it is necessary to investigate the bioaccumulation of heavy metals in tissue of organism.

\section{Sampling}


Based on the habitat, human activities and topographic characteristics, the Aras River was separated into four sections. The field sampling was conducted within the period from October 2017 to November, 2020. Totally 172 samples (70 adult fish and 102 Amphipoda) were collected from 21 sites. The study area map and sampling was shown in figure 2 .

\section{Heavy metals analyzes}

After collecting the specimens and sampling, the specimens were put in plastic bags containing powdered ice, transferred to the laboratory, and kept in a freezer at $-20^{\circ} \mathrm{C}$ until they were tested. In the laboratory, their total weights were determined using a digital scale with an accuracy of $0.001 \mathrm{~g}$. Extracted muscle $(1 \pm 0.001 \mathrm{gr})$ and Cuticle tissue samples $(1 \pm 0.001 \mathrm{gr})$ were stored at $-20^{\circ} \mathrm{C}$. The dissected tissues were separately placed in Petri dishes and put in an oven at $110^{\circ} \mathrm{C}$ for drying the samples to constant weight $(24 \mathrm{~h})$. The dried tissues were grounded in a china mortar and pestle, and $1 \mathrm{~g}$ of each one was poured in a 100-ml Erlenmeyer flask and then $10 \mathrm{ml}$ of $60 \%$ nitric acid was added and the flask was kept for 2 hours at room temperature for preliminary digestion. The samples were then put on a hot plate at $140{ }^{\circ} \mathrm{C}$ for $5 \mathrm{~h}$ for the complete digestion of the samples. Then, they were passed through a 42-micron paper filter and water was added to adjust the volume at $25 \mathrm{ml}$ (Mehmood et al. 2020). We included 10 blanks in digestion and analysis procedures as controls. Results of element levels are expressed as $\mu \mathrm{g} / \mathrm{g}$ of dry weight.

\section{Chemical analysis}

Concentrations of the heavy metals in the prepared samples were determined using an Atomic Absorption Spectrometery (Model: Aurora, Trace Al1200). Limits of detection for the metals were as follows: As and $\mathrm{Pb}$ were $0.05 \mu \mathrm{g} / \mathrm{L}$ for $\mathrm{Cd}$ was $0.01 \mu \mathrm{g} / \mathrm{L}$ and $\mathrm{Cu}$ was $0.1 \mu \mathrm{g} / \mathrm{L}$. Determined element concentration $(\mu \mathrm{g} / \mathrm{g})$ in fish muscle tissue in this study compared to the Maximum Allowable Concentration (MAC) in fish meat used for human diets published by the different organization and other studies worldwide (Table 5).

\section{Quality control and quality assurance}

All labware was washed with $10 \% \mathrm{HNO}$, and only ultrapure water was used for sample digestion and preparation.

All samples were analyzed in duplicate to improve the accuracy of the amounts. The standard deviation was less than $9 \%$ in the batch treatments and results are expressed as mean \pm standard deviation. Sample spiking and recovery rates for $\mathrm{As}, \mathrm{Pb}, \mathrm{Cd}$ and $\mathrm{Cu}$, were $92.5,95.4,97.2$ and $93.5 \%$, respectively. Quality of analyses was controlled using the certified reference material (DOLT-4-certified) fish muscle, supplied by the National Research Council of Canada (NRC).

\section{Statistical analysis}


Statistical analyzes were performed using SPSS (ver. 22) software. The mean and standard error of heavy metal concentrations were calculated. One-way analysis of variance (ANOVA) was performed to comparison of $\mathrm{As}, \mathrm{Pb}, \mathrm{Cd}$, and $\mathrm{Cu}$ concentrations among stations by season and organism. In order to compare the concentrations of heavy metals between Gammarus spp. and fish body in different stations by season, t-test was used. Mann-Whitney $U$ test was used to comparison of heavy metal concentrations between Gammarus spp. and fish body in general. Kruskal-Wallis $\mathrm{H}$ test was applied to identify significant differences of the targeted elements in Gammarus sp. and fish body among seasons; and then a pairwise comparison performed using the Mann-Whitney $U$ test. For all tests, a two-tailed $P$ value of $<0.05$ was considered significant.

\section{Risk assessment analyzes}

\section{The target hazard quotients (THQ)}

Target Hazard Quotients (THQ) is an index for assessing the potential non-carcinogenic effects of food materials such as fish species exposed to heavy metals contamination. If the value of this index is less than 1 , it means that the consumed fish have fewer undesirable effects on human whereas values higher than 1 indicates that eating the fish will have very harmful effects on human. It is calculated following the USEPA (2012) equations:

$\mathrm{THQ}=\frac{E F \times E D \times F I R \times C}{R f D \times B W \times T A} \times 10^{-3}$

Where; EF: exposure frequency (365 days/year), ED: exposure duration (70 years); FIR: fish ingestion rate (36 g/person/day; FAO, 2005); C: metal concentration ( $\mu \mathrm{g} / \mathrm{g})$; RfD: reference oral dose (Table 1. mg $/ \mathrm{kg}$ bw day; USEPA, 2012); Bw: average body weight for adult consumer (67 kg); TA: mean exposure time for non-carcinogens (EF×ED).

\section{Total target hazard quotient (TTHQ)}

Since the pollution may have been caused by two or more heavy metals, the total THQ index (TTHQ) is used to evaluate the effects of these metals. It was calculated as the sum of the hazard quotients (Chien et al. 2002):

$\mathrm{TTHQ}=\mathrm{THQ}_{(\mathrm{As})}+\mathrm{THQ}_{(\mathrm{Pb})}+\mathrm{THQ}_{(\mathrm{Cd})}+\mathrm{THQ}_{(\mathrm{Cu})}$

\section{Carcinogenic Risk (CR):}

CR is the cancer risk index for an individual who has used all his/her life the class of food materials that have been exposed to carcinogens (USEPA, 2010). Among the studied metals, cadmium, lead, and arsenic are classified as carcinogens (Kortei et al. 2020). This index is calculated using the following formula: 
$\mathrm{CR}=\frac{E F \times E D \times F I R \times C \times C S F}{\bar{B} W \times T A} \times 10^{-3}$

According to New York State Department of Health [NYSDOH (New York State Department of Health) 2007] the $C R$ categories are described as, if $C R \leq 1 \times 10^{-6}=$ Low; $10^{-4}$ to $10^{-3}=$ moderate; $10^{-3}$ to $10^{-1}$ = high; $\geq 10^{-1}=$ very high. Here, CSF is cancer slope factors (mg/ kg day) (Table 1).

Since zander is directly in the food chain of the people in the region, THQ, TTHQ, and CR were calculated only for this fish species.

\section{Results And Discussions}

\section{The concentrations of heavy metals in the studied specimens}

Table 2 presents the concentrations of the studied heavy metals in zander muscles and in the body of the amphipod specimens.

\section{Arsenic}

The lowest concentration of arsenic $(0.58 \mu \mathrm{g} / \mathrm{g})$ in zander was recorded at station 1 in summer and Autumn; and the highest concentration $(1.25 \mu \mathrm{g} / \mathrm{g})$ was found at station 1 in summer. The values in Gammarus sp. specimens $(0.40-0.96 \mu \mathrm{g} / \mathrm{g})$ were similar to those in zander (Table 2). In addition, the average concentration $(0.838 \mu \mathrm{g} / \mathrm{g})$ of Arsenic in zander muscles were larger compared to those in studies conducted in other regions such as the Danube River in Serbia $(0.66 \mu \mathrm{g} / \mathrm{g})$ and the Seine, Escaut, and Rhône Rivers $(0.119 \mu \mathrm{g} / \mathrm{g})$ in France (Table 4).

\section{Cadmium}

The lowest amount of this metal in zander $(0.36 \mu \mathrm{g} / \mathrm{g})$ was observed at station 4 in summer and the highest value $(1.1 \mu \mathrm{g} / \mathrm{g})$ was found at station 2 in summer (Table 2). The corresponding values for Gammarus sp. specimens were recorded at station 4 in summer $(0.22 \mu \mathrm{g} / \mathrm{g})$ and at station 2 in summer and Autumn $(0.84 \mu \mathrm{g} / \mathrm{g})$. The average value of this metal $(0.7 \mu \mathrm{g} / \mathrm{g})$ in zander at the four studied stations was smaller than other studies including those in Kayseri and Lake Beyşehir in Turkey (2.52 $\mu \mathrm{g} / \mathrm{g}$; Yildirim et al. 2009 and $2.17 \mu \mathrm{g} / \mathrm{g}$; Özparlak et al., 2012, respectively) and larger than compared to those in studies conducted in other regions such the Danube River in Serbia $(0.005 \mu \mathrm{g} / \mathrm{g}$; Subotić et al., 2013), Seine, Escaut, and Rhône Rivers in France $(0.001 \mu \mathrm{g} / \mathrm{g}$; Noël et al. 2013), Sidi Salem Reservoir in

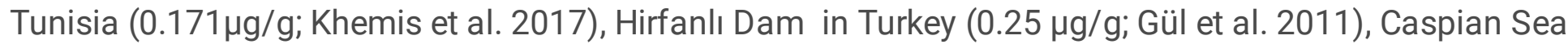
$(0.09 \mu \mathrm{g} / \mathrm{g}$; Alipour and Banagar. 2018) and the Velenjsko jezero in Slovenia ( $₫ 0.01 \mu \mathrm{g} / \mathrm{g}$; Mazej et al. 2010).

\section{Lead}


The lowest amount of this metal in zander $(0.5 \mu \mathrm{g} / \mathrm{g})$ was measured at station 4 in spring and the highest $(0.93 \mu \mathrm{g} / \mathrm{g})$ at station 3 in summer. The corresponding values for Gammarus sp. specimens were $(0.40$ $\mu \mathrm{g} / \mathrm{g})$ at station 4 in spring and $(0.66 \mu \mathrm{g} / \mathrm{g})$ at station 3 in summer (Table 2). The average value of concentration $(0.71 \mu \mathrm{g} / \mathrm{g})$ in zander was smaller than those reported from Beyşehir Lake in Turkey (0.162 $\mu \mathrm{g} / \mathrm{g}$; Özparlak et al. 2012) and larger than compared to those recorded from Kayseri Lake in Turkey ( $₫ 0.03$; Yildirim et al. 2009), Seine, Escaut and Rhône Rivers in France (0.008 $\mu \mathrm{g} / \mathrm{g}$; Noël et al. 2013), Sidi Salem Reservoir in Tunisia (0.046 $\mu \mathrm{g} / \mathrm{g}$; Khemis et al. 2017), Hirfanlı Dam in Turkey $(0.65 \mu \mathrm{g} / \mathrm{g}$; Gül et al. 2011), Caspian Sea (0.53 $\mu \mathrm{g} / \mathrm{g}$; Alipour and Banagar. 2018), and Velenjsko jezero in Slovenia ( $₫ 0.03$ $\mu \mathrm{g} / \mathrm{g}$; Mazej et al. 2010).

\section{Copper}

The smallest amount of this metal $(0.48 \mu \mathrm{g} / \mathrm{g})$ was recorded at station 1 in spring and the largest $(0.88$ $\mu \mathrm{g} / \mathrm{g})$ at station 2 in winter. The corresponding values for Gammarus sp. specimens were $(0.34 \mu \mathrm{g} / \mathrm{g})$ at station 1 in fall and $(0.67 \mu \mathrm{g} / \mathrm{g})$ at station 3 in spring, respectively (Table 2$)$.

Statistically significant differences were found among Gammarus sp. specimens of various stations in each season and among zander specimens from different stations in each season, except spring, in the concentrations of Cd; and among stations for both Gammarus and zander samples in each season, except spring, in the concentrations of As. Using Duncan post hoc test, it was found that the Cd concentration of Gammarus sp. specimens from stations 1 and 2 are statistically different from each other and from stations 3 and 4 in the spring and summer; also stations 2 and 3 are different from each other and from the other two stations in the autumn and winter. As well, the test revealed that only As concentration of zander specimens from station 1 is different from other stations in three seasons (Table $3)$.

Concentrations of heavy metals in fish body are higher than its prey at each station in different seasons. It was observed that at station 1 for each heavy metal, the concentrations in the body of the fish is significantly higher than the concentrations in Gammarus sp., except Pb in spring. Also, the concentrations of $\mathrm{Cd}$ in the body of fish is higher than Gammarus sp. in most stations by season (Table $3)$.

The concentrations of heavy metals among season in Gammarus sp. body are not statistically significant; and in fish body except for $\mathrm{Pb}$. A pairwise comparison showed that the amount of $\mathrm{Pb}$ in the fish body in spring is significantly lower than other seasons (Kruskal-Wallis $\chi 2=18.65, p<0.0005$ ) (Table 4).

In general, the concentration of each heavy metal in the body of fish was significantly higher than Gammarus spp. and the values obtained for $\mathrm{As}, \mathrm{Pb}$ and $\mathrm{Cd}$ in Zander muscle tissue exceeded the permissible limits in the standards set by the various organizations (Table 5).

\section{Health risk assessment}


The THQs of the heavy metals in all stations was as follows: $\mathrm{As}>\mathrm{Cd}>\mathrm{Pb}>\mathrm{Cu}$.

Values of target hazard quotient (THQ), total target hazard quotient (TTHQ) calculated for zander. The values of THQ were higher than 1 at all stations only for arsenic among the four studied heavy metals. The values of TTHQ were higher than 1 at all stations, but it was the highest $(>2)$ at station 2 . The values of $\mathrm{CR}_{\mathrm{cd}}$ at all stations were more than $10^{-3}$, which indicates the high level of evidence of human carcinogenicity for this metal in this river. $\mathrm{CR}_{\mathrm{As}}$ with a value more than $10^{-4}$ ranked second in this regard indicating an intermediate level of evidence of human carcinogenicity for arsenic (Table 6).

The data demonstrated that there was a positive relationship between the prey and the predator, and the values of the heavy metals in zander (the predator) were higher compared to the amphipod (the prey) confirming the principle of biomagnification. Moreover, among the four heavy metals, the mean values of lead concentrations in zander $(0.84 \mu \mathrm{g} / \mathrm{g})$ and in the amphipod $(0.59 \mu \mathrm{g} / \mathrm{g})$ were higher compared to the other heavy metals, which indicated the high sensitivity of zander to lead. The calculated THQ for arsenic exceeded the international standards and are harmful for the consumers of this fish. At all stations, the values of $\mathrm{CR}_{\mathrm{Cd}}$ were $>1 \times 10^{-3}$, which showed the degree of evidence of carcinogenicity of this metal in all parts of the Aras River.

Unfortunately, no comprehensive research has been conducted on the heavy metals in the bodies of organisms living in the Aras River except for the study by Nasehi et al. (2012-2013) who investigated the concentrations of heavy metals in carp muscles and did not detect any cadmium or lead deposition in this fish species. However, in the present research, the amounts of both of these metals at station 2, which showed the highest quantities of these two metals deposited in this fish species among all the stations, exceeded the international standard in all seasons. The calculated value of TTHQ $(>2)$ for this station indicates the critical situation in the area, which probably resulted from the application of pesticides and chemical fertilizers.

In general, the amounts of the studied metals in zander exhibited ascending trends in spring and summer compared to the other two seasons mainly because of the extensive use of phosphorus fertilizers in agriculture and also the greater activity of industries and mines in these two seasons than in fall and winter in this cold region when use of phosphorus fertilizers and the activities in the industries and mines decrease leading to reduced pollution.

\section{Conclusions}

Considering the high values of $\mathrm{CR}_{\mathrm{cd}}\left(>10^{-3}\right)$ and $\mathrm{CR}_{\mathrm{As}}\left(>10^{-4}\right)$, especially in spring and summer, if management measures concerning entry of pesticides and chemical fertilizers and effluent discharges from the adjacent mines into the river tributaries are not correctly taken, irreparable damage will be inflicted on the sensitive ecosystems of this river and the human communities living close to the river. In addition, periodic removal of the various contaminants in this river, especially in the areas located at station 2, can be an effective step in becoming aware of the environmental situation. Based on the 
present research, it is recommended that zander and amphipod can be used as bioindicators in assessing the extent of pollution in the various parts of the Aras River and its tributaries as the introduced models are abundantly found in this river and catching and sampling them can also be easily done.

\section{Declarations}

Ethics approval and consent to participate: Not applicable

Consent for publication: Not applicable

Availability of data and materials: The datasets used and/or analysed during the current study are available from the corresponding author on reasonable request.

Competing interests: The authors declare that they have no competing interests

Funding: Not applicable

Authors' contributions: Amir Dehghani was collected materials and analyzed and interpreted the Heavy metals. Atabak Roohi performed the analyzed of heavy metals in Amphipoda. Allahverdi Dehgani was a major contributor in writing the manuscript. All authors read and approved the final manuscript."

Acknowledgemen: Not applicable

\section{References}

Ahsanullah M, Williams AR (1991) Sublethal effects and bioaccumulation of cadmium, chromium, copper and zinc in the marine amphipod Allorchestes compressa. Mar Biol 108:59-65.

Alipour H, Banagar G (2018) Health risk assessment of selected heavy metals in some edible fishes from Gorgan Bay, Iran. Iran J Fish Sci 17(1):21-34. https://doi.org/ 10.22092/IJFS.2018.115582.

Altındağ A, Yiğit S (2005) Assessment of heavy metal concentrations in the food web of lake Beyşehir, Turkey. Chemosphere 60(4): 552-556. https://doi.org/10.1016/j.chemosphere.2005.01.009.

Asuquo FE, Ewa-Oboho I, Asuquo EF, Udo PJ (2004) Fish species used as biomarker for heavy metal and hydrocarbon contamination for Cross River, Nigeria. Environmentalist 24:29-37.

https://doi.org/10.1023/B:ENVR.0000046344.04734.39

Bach L, Ferguson L, Feltelius V, Sondergaard J (2014) Orchomenella pinguis (amphipoda) a possible species for heavy metal biomonitoring of marine sediments. J Coast Life Med 2:116-123. https://doi.org/ 10.12980/JCLM.2.2014J29.

Bessa F, Scapini F, Cabrini TMB, Cardoso RS (2017) Behavioural responses of talitrid amphipods to recreational pressures on oceanic tropical beaches with contrasting extension. J Exp Mar Biol Ecol 
486:170-177. https://doi.org/10.1016/j.jembe.2016.10.007.

Çelekli A, Kayhan S, Çetin T (2020) First assessment of lakes' water quality in Aras River catchment (Turkey); Application of phytoplankton metrics and multivariate approach. Ecological Indicators 117: 106706. https://doi.org/10.1016/j.ecolind.2020.106706

Chien LC, Hung TC, Choang KY, Yeh CY, Meng PJ, Shieh MJ, Ha BC (2002) Daily intake of tbt, cu, zn, cd and as for fishermen in taiwan. Sci Total Environ 285:177-85. https://doi.org/10.1016/S00489697(01)00916-0

Coad BW (2016) Review of the Perches of Iran (Family Percidae). International Journal of Aquatic Biology, 4(3): 143-170

European Commission Regulation, (2006) Setting maximum levels for certain contaminants in foodstuffs. Official Journal of the European Union, Commission Regulation No. 1881/2006/EC

FAO/WHO, Summary and Conclusions of the Sixty-First Meeting of the Joint FAO/ WHO Expert Committee on Food Additives (JECFA) (2003), World Health Organization, Rome, Italy

FAO/WHO Codex Alimentarius. CODEX STAN 193-1995 general standard for contaminants and toxins in food and feed. In: Nat. Toxins. 2009. http://www.fao.org/fileadmin/user_upload/

Farsani MN, Haghparast RJ, Naserabad SS, Moghadas F, Bagheri T, Gerami MH, 2019. Seasonal heavy metal monitoring of water, sediment and common carp (Cyprinus carpio) in Aras dam Lake of Iran. International Journal of Aquatic Biology 7(3): 123-131

Fialkowski W, Calosi P, Dahlke S, Dietrich A, Moore PG, Olenin S, Persson LE, Smith BD, Špegys M, Rainbow PS (2009) The sandhopper Talitrus saltator (Crustacea: Amphipoda) as a biomonitor of trace metal bioavailabilities in European coastal waters. Mar Poll Bull 58:39-44.

https://doi.org/10.1016/j.marpolbul.2008.09.013.

Fialkowskia W, Rainbow PS, Smith BD, Zmudzinski L (2003) Seasonal variation in trace metal concentrations in three talitrid amphipods from the Gulf of Gdansk, Poland. J Exp Mar Biol Ecol 288:8193. https://doi.org/10.1016/S0022-0981(02)00594-4.

Guerra-García JM, Ruiz-Tabares A, Baeza-Rojano E, Cabezas MP, Díaz-Pavón JJ, Pacios I, Maestre M, González AR, Espinosa F, García-Gómez JC (2010) Trace metals in Caprella (Crustacea: Amphipoda). A new tool for monitoring pollution in coastal areas. Ecol Indic 10(3):734-743.

https://doi.org/10.1016/j.ecolind.2009.12.003.

Gül A, Yılmaz M, Benzer S, Taşdemir L (2011) Investigation of zinc, copper, lead and cadmium accumulation in the tissues of Sander lucioperca (L., 1758) living in Hirfanlı Dam Lake, Turkey. Bull Environ Contam Toxicol 87(3):264-266. https://doi.org/10.1007/s00128-011-0350-8 
Hogan MC (2010) Heavy metal. In: Monosson E, Cleveland C (eds) Encyclopedia of earth. National Council for Science and the Environment Washington

Integrated Risk Information System (IRIS) (2011) Manganese; CASRN 7439-96-5. US

Jelassi R, Khemaissia H, Ghemari C, Raimond M, Souty-Grosset C, Nasri-Ammar K (2019)

Ecotoxicological effects of trace element contamination in talitrid amphipod Orchestia montagui Audouin, 1826. Environ Sci Pollut Res 26:5577-5587. https://doi.org/ 10.1007/s11356-018-3974-y

Jelassi R, Khemaissia H, Zimmer M, Garbe-Schönberg D, Nasri-Ammar K (2015) Biodiversity of talitridae family (Crustacea, Amphipoda) in some Tunisian coastal lagoons. Zool Stud 54(1):17. https://doi.org/ 10.1186/s40555-014-0096-1.

Kalyoncu L, Kalyoncu H, Arslan G (2012) Determination of heavy metals and metals levels in five fish species from Isıkı Dam Lake and Karacaören Dam Lake (Turkey). Environmental Monitoring and Assessment 184: 2231-2235. https://doi.org/10.1007/s10661-011-2112-9.

Khemis IB, Besbes Aridh N, Hamza N, M'Hetli M, Sadok S (2017) Heavy metals and minerals contents in pikeperch (Sander lucioperca), carp (Cyprinus carpio) and flathead grey mullet (Mugil cephalus) from Sidi Salem Reservoir (Tunisia): health risk assessment related to fish consumption. Environ Sci Pollut Res Int 24:19494-19507 https://doi.org/10.1007/s11356-017-9586-0.

Kiffney PM, Clements WH (1994) Effects of heavy metals on a macroinvertebrate assemblage from a Rocky Mountain stream in experimental microcosms. Journal of the North American. Benthological Society 13:511-523. https://doi.org/10.2307/1467847

Kontchou JA, Nachev M, Sures B (2020) Ecotoxicological effects of traffic-related metal sediment pollution in Lumbriculus variegatus and Gammarus sp. Environmental Pollution 268: 115884. https://doi.org/10.1016/j.envpol.2020.115884.

Kortei NK, Heymann ME, Essuman EK, Kpodo FM, Akonor PT, Lokpo SY, Boadi NO, Ayim-Akonor M, Tettey C (2020) Health risk assessment and levels of toxic metals in fishes (Oreochromis noliticus and Clarias anguillaris) from Ankobrah and Pra basins: Impact of illegal mining activities on food safety Toxicol. Rep 7: 360-369. https://doi.org/10.1016/j.toxrep.2020.02.011.

Kunz PJ, Kienle C, Gerhardt A (2010) Gammarus spp. in aquatic ecotoxicology and water quality assessment: toward integrated multilevel tests. Rev Environ Contam Toxicol 205:1-76.

https://doi.org/10.1007/978-1-4419-5623-1_1

Langston WJ, Spence SK (1995) Biological factors involved in metal concentrations observed in aquatic organisms. In: Tessier A, Turner DR (eds) Metal speciation and bioavailability in aquatic systems. IUPAC, Wiley, pp 407-478. 
Malvandi H, Alahabadi A (2019) Evaluation of potential human health risk due to the exposure to mercury via fish consumption of Alosa spp. from the southern Caspian Sea. Mar Pollut Bull 143:66-71. https://doi.org/10.1016/j.marpolbul.2019.04.042.

Mazej Z, Al Sayegh-Petkovsek S, Pokorny B (2010) Heavy metal concentrations in food chain of Lake Velenjsko Jezero, Slovenia: an artificial lake from mining. Arch Environ Contam Toxicol 58:998-1007. https://doi.org/10.1007/s00244-009-9417-5

Mehmood R, Imran U, Ullah A, Ullman JL, Weidhaas J, (2020) Health risks associated with accumulation of heavy metals in fish of Keenjhar Lake, Pakistan. Environmental Science and Pollution Research 27(19): 24162-24172. https://doi.org/ 10.1007/s11356-020-08705-4

Mohammed AS, Kapri A, Goel R (2011) Heavy metal pollution: source, impact, and remedies. Environ Pollut 20:1-28. https://doi.org/10.1007/978-94-007-1914-9_1

Nasehi F, Hassani A, Monavvari M, Karbassi A, Khorasani N, Imani A (2012) Heavy metal distributions in water of the Aras River, Ardabil, Iran. J Water Resour Protect 4:73-78.

Nasehi F, Monavari M, Naderi G, Vaezi MA, Madani F (2013) Investigation of heavy metals accumulation in the sediment and body of carp fish in Aras River. Iran J Fish Sci 12:398-410.

Noël L, Chekri R, Millour S, Merlo M, Leblanc J-C, Guérin T (2013) Distribution and relationships of As, Cd, $\mathrm{Pb}$ and $\mathrm{Hg}$ in freshwater fish from five French fishing areas. Chemosphere 90(6):1900-10. https://doi.org/10.1016/j.chemosphere.2012.10.015.

Noel L, Chekri R, Millour S, Merlo M, Leblanc JC, Guerin T (2013) Distribution and relationships of As, Cd, $\mathrm{Pb}$ and $\mathrm{Hg}$ in freshwater fish from five French fishing areas. Chemosphere 90 (6):1900-1910. https://doi.org/10.1016/j.chemosphere.2012.10.015.

Ouyang Y, Higman J, Thompson J, Toole OT, Campbell D (2002) Characterization and spatial distribution of heavy metals in sediment from Cedar and Ortega Rivers sub-basin. J Contam Hydrol 54:19-35. https://doi.org/10.1016/S0169-7722(01)00162-0.

Özparlak H, Arsla G, Arslan E (2012) Determination of some metal levels in muscle tissue of nine fish species from Beyşehir Lake, Turkey. Turk J Fish Aquat Sci 12(4):761-770. https://doi.org/10.4194/13032712-v12_4_04.

Popov PA, Vizer AM, Androsova NV (2012) Metal content in muscular tissue of commercially important fish from Novosibirsk reservoir and near dam on Ob' River. Contemporary Problems of Ecology 5(4): 352355. https://doi.org/10.1134/S1995425512040117.

Rashed MN (2001) Monitoring of environmental heavy metals in fish from Nasser Lake. Environ Int 27:27-33. https://doi.org/10.1016/S0160-4120(01)00050-2. 
Strode E, Balode M, (2013) Toxico-resistance of baltic amphipod species to heavy metals. Crustaceana 86: 1007-1024. https://doi.org/10.1163/15685403-00003208

Subotić S, Spasić S, Višnjić-Jeftić Ž, Hegediš A, Krpo-Ćetković J, Mićković B, Skorić S, Lenhardt M (2013) Heavy metal and trace element bioaccumulation in target tissues of four edible fish species from the Danube River (Serbia). Ecotoxicol Environ Saf 98:196202.https://doi.org/10.1016/j.ecoenv.2013.08.020.

Subotić S, Spasić S, Višnjić-Jeftić Ž, Hegediš A, Krpo-Ćetković J, Mićković B, Skorić S, Lenhardt M (2013) Heavy metal and trace element bioaccumulation in target tissues of four edible fish species from the Danube River (Serbia). Ecotoxicol Environ Saf 98:196-202.

https://doi.org/10.1016/j.ecoenv.2013.08.020.

Tchounwou PB, Yedjou CG, Patlolla AK, Sutton DJ (2012) Heavy metals toxicity and the environment. EXS 101:133-164. https://doi.org/10.1007/978-3-7643-8340-4_6

USEPA (2010) Risk-based concentration table. United State Environmental Protection Agency, Washington, DC

USEPA, Edition of the Drinking Water Standards and Health Advisories. EPA 822-S12-001, 2012 Edition of the Drinking Water Standards and Health Advisories, Office of Water, U.S. Environmental Protection Agency, Washington, DC, 2012.

Uysal K, Köse E, Bülbül M, Dönmez M, Erdoğan Y, Koyun M, Ömeroğlu C, Özmal F (2009) The comparison of heavy metal accumulation ratios of some fish species in Enne Dame Lake (Kütahya/Turkey). Environ Monit Assess 157:355-362. https://doi.org/10.1007/s10661-008-0540-y.

Yildirim Y, Gonulalan Z, Narin I, Soylak M (2008) Evaluation of trace heavy metal levels of some fish species sold at retail in Kyseri, Turkey. Environ Monit Assess 149:223-228. https://doi.org/ 10.1007/s10661-008-0196-7.

Zhang X, Yang L, Li Y, Li H, Wang W, Ye B (2012) Impacts of lead/zinc mining and smelting on the environment and human health in China. Environ Monit Assess 184:2261-2273.

https://doi.org/10.1007/s10661-011-2115-6.

\section{Tables}

Tables 1-6 are available in the Supplementary Files.

\section{Figures}




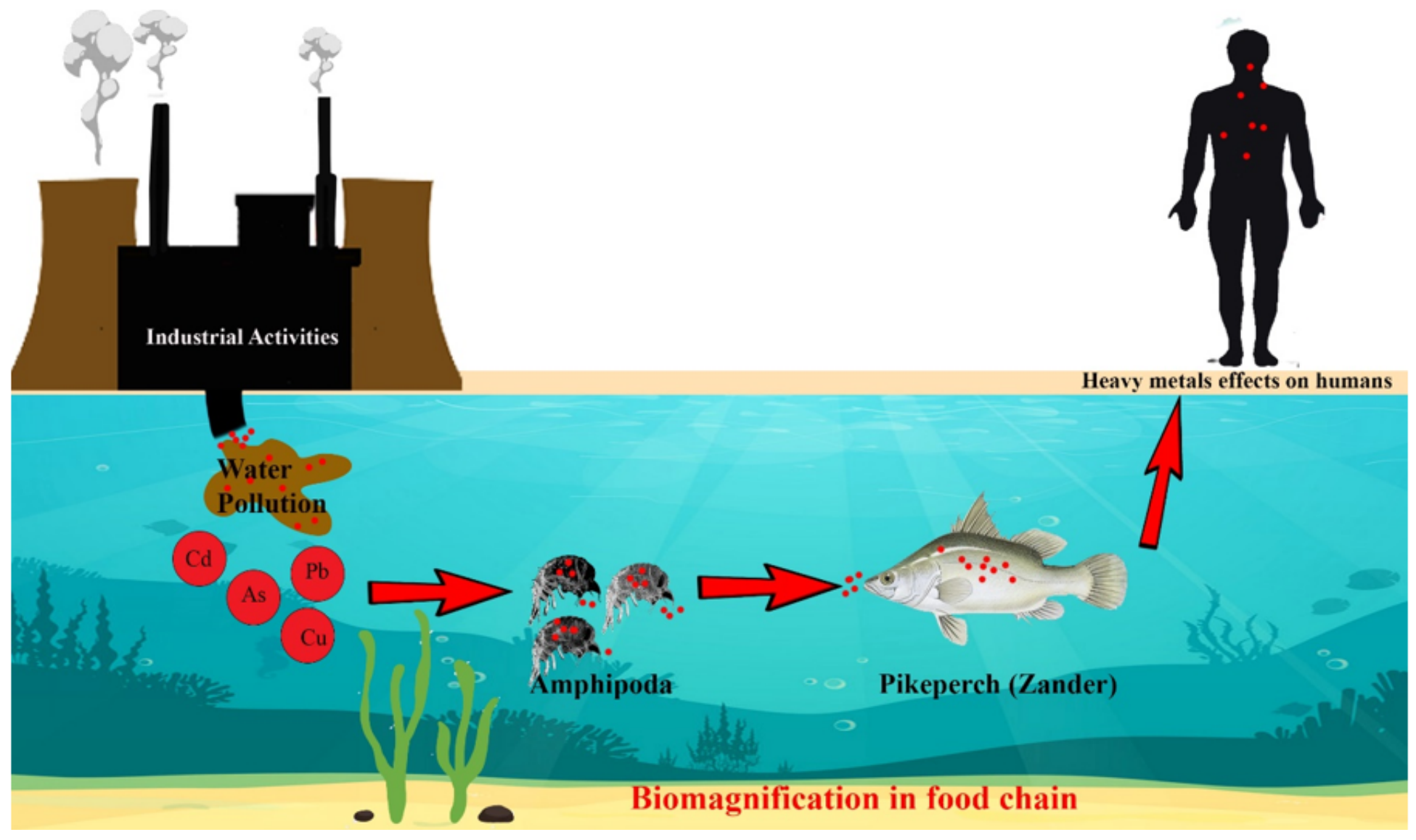

Figure 1

A schematic model of bioaccumulation of heavy metals in aquatic food chain. 


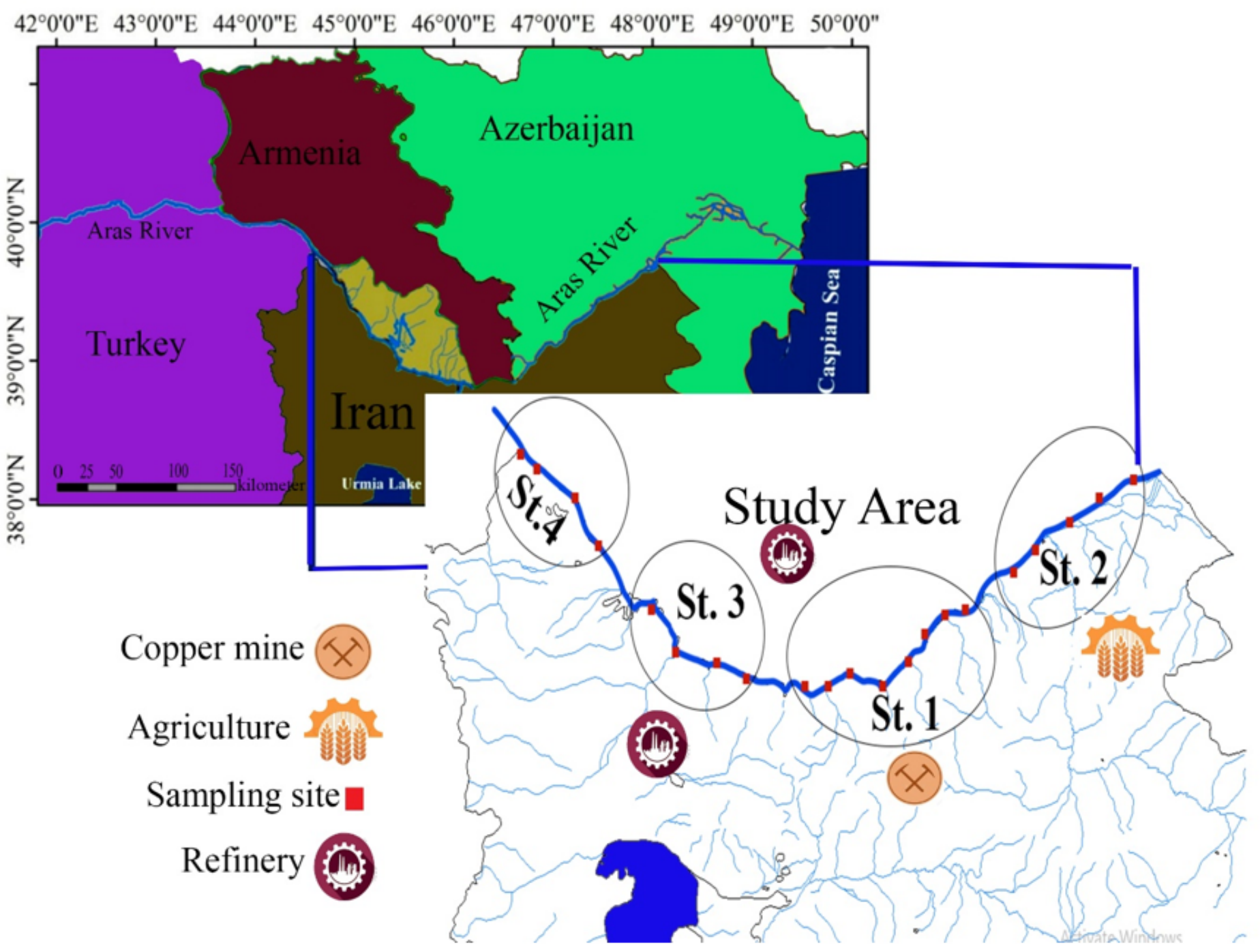

Figure 2

Map of the study area and sampling station with source of heavy metal pollution. Note: The designations employed and the presentation of the material on this map do not imply the expression of any opinion whatsoever on the part of Research Square concerning the legal status of any country, territory, city or area or of its authorities, or concerning the delimitation of its frontiers or boundaries. This map has been provided by the authors.

\section{Supplementary Files}

This is a list of supplementary files associated with this preprint. Click to download.

- Tables.docx 